\title{
Bozepinib, a novel small antitumor agent, induces PKR-mediated apoptosis and synergizes with IFN $\alpha$ triggering apoptosis, autophagy and senescence
}

\author{
This article was published in the following Dove Press journal: \\ Drug Design, Development and Therapy \\ 25 October 2013 \\ Number of times this article has been viewed
}

\author{
Juan Antonio Marchal ${ }^{1,2}$ \\ Esther Carrasco' \\ Alberto Ramirez ${ }^{1,3}$ \\ Gema Jiménez ${ }^{1,2}$ \\ Carmen Olmedo 4 \\ Macarena Peran ${ }^{1,3}$ \\ Ahmad Agil ${ }^{5}$ \\ Ana Conejo-García ${ }^{6}$ \\ Olga Cruz-López \\ Joaquin María Campos ${ }^{6}$ \\ María Ángel García ${ }^{4,7}$ \\ 'Biopathology and Regenerative \\ Medicine Institute, Centre for \\ Biomedical Research, ${ }^{2}$ Department \\ of Human Anatomy and Embryology, \\ Faculty of Medicine, University of \\ Granada, Granada, ${ }^{3}$ Department of \\ Health Sciences, University of Jaén, Jaén, \\ ${ }^{4}$ Experimental Surgery Research Unit, \\ Virgen de las Nieves University Hospital, \\ Granada, ${ }^{5}$ Department of Pharmacology \\ and Neurosciences Institute, \\ Faculty of Medicine, ${ }^{6}$ Department of \\ Pharmaceutical and Organic Chemistry, \\ Faculty of Pharmacy, University of \\ Granada, Granada, ${ }^{7}$ Departmen \\ of Oncology, Virgen de las Nieves \\ University Hospital, Granada, Spain
}

Correspondence: María Ángel García Hospital Universitario Virgen de las Nieves, E-18012 Granada, Spain

$\mathrm{Tel}+34958249321$

Fax +34958246296

Email mangelgarcia@ugr.es

Juan Antonio Marchal

Universidad de Granada, E-18100

Granada, Spain

$\mathrm{Tel}+34958249321$

Fax +34958246296

Email jmarchal@ugr.es

\begin{abstract}
Bozepinib [(RS)-2,6-dichloro-9-[1-( $p$-nitrobenzenesulfonyl)-1,2,3,5-tetrahydro-4,1benzoxazepin-3-yl]-9H-purine] is a potent antitumor compound that is able to induce apoptosis in breast cancer cells. In the present study, we show that bozepinib also has antitumor activity in colon cancer cells, showing 50\% inhibitory concentration $\left(\mathrm{IC}_{50}\right)$ values lower than those described for breast cancer cells and suggesting great potential of this synthetic drug in the treatment of cancer. We identified that the double-stranded RNA-dependent protein kinase (PKR) is a target of bozepinib, being upregulated and activated by the drug. However, p53 was not affected by bozepinib, and was not necessary for induction of apoptosis in either breast or colon cancer cells. In addition, the efficacy of bozepinib was improved when combined with the interferon-alpha (IFN $\alpha$ ) cytokine, which enhanced bozepinib-induced apoptosis with involvement of protein kinase PKR. Moreover, we report here, for the first time, that in combined therapy, IFN $\alpha$ induces a clear process of autophagosome formation, and prior treatment with chloroquine, an autophagy inhibitor, is able to significantly reduce IFN $\alpha /$ bozepinib-induced cell death. Finally, we observed that a minor population of caspase 3-deficient MCF-7 cells persisted during long-term treatment with lower doses of bozepinib and the bozepinib/IFN $\alpha$ combination. Curiously, this population showed $\beta$-galactosidase activity and a percentage of cells arrested in $\mathrm{S}$ phase, that was more evident in cells treated with the bozepinib/IFN $\alpha$ combination than in cells treated with bozepinib or IFN $\alpha$ alone. Considering the resistance of some cancer cells to conventional chemotherapy, combinations enhancing the diversity of the cell death outcome might succeed in delivering more effective and less toxic chemotherapy.
\end{abstract}

Keywords: seven-member heterocycles, purines, $\mathrm{IC}_{50}$, interferon cytokine, cell death, breast and colon cancer cells

\section{Introduction}

The mortality to incidence ratio in cancer patients is extremely high, positioning cancer as a major cause of death worldwide. ${ }^{1}$ Chemotherapy has a role as either strategic treatment for locally advanced disease or palliative treatment for metastatic tumors. However, clinical use of chemotherapy is still unsatisfactory due to limited response rates, a small survival benefit, and a poor prognosis. Therefore, more effective and safer anticancer drugs are urgently needed. In this sense, combination therapies that enhance efficacy or permit administration of reduced doses have been successfully used in a broad variety of therapeutic applications.

Previous studies have demonstrated the potent antiproliferative activity of pyrimidine and purine benzo-fused seven-membered $O, N$-acetals in human breast and colon cancer 
cell lines in the micromolar range..$^{2-4}$ Bozepinib shows a $50 \%$ inhibitory concentration $\left(\mathrm{IC}_{50}\right)$ of $0.166 \mu \mathrm{M}$ against the MDAMB-231 human breast adenocarcinoma cell line. Moreover, this compound is able to selectively induce high levels of apoptosis in tumor cells and shows no acute toxicity in mice. ${ }^{5}$

Many chemotherapeutic drugs eradicate cancer cells by inducing apoptosis, and regardless of their primary targets, many are similar in terms of the cellular response to the apoptosis induced. ${ }^{6}$ However, many tumors have a seriously compromised apoptosis pathway, and new drugs inducing other cytotoxic effects must be explored in order to evade chemoresistance. Therefore, although apoptosis has been considered as the typical mechanism for cell death, accumulating evidence suggests that alternative cell death pathways play a role in the tumor response to chemotherapy. ${ }^{7,8}$ A potential mechanism of caspase-independent cell death is autophagy, which is defined as controlled lysosomal degradation of macromolecules and organelles. Autophagy was initially identified as a cell survival mechanism to protect against nutrient deprivation; ${ }^{9}$ however, in certain conditions, it results in a form of cell death now described as type II programmed cell death, which is being targeted for novel therapeutic strategies in cancer. ${ }^{10}$

Senescence was first described as a state of irreversible growth arrest that normal human fibroblasts enter into at the end of their replicative lifespan. ${ }^{11}$ By restricting cell proliferation and thereby impeding the accumulation of mutations, senescence acts as an important tumor suppression mechanism. Further, senescence induced by aberrant activation of oncogenes, oxidative stress, or DNA damage prevents proliferation of cells at risk of malignant transformation. Therefore, senescence offers an attractive therapeutic option if it can be induced in tumor cells. ${ }^{12}$

Interferons (IFNs) are agents with antiviral, antiproliferative, and immunomodulatory properties. Interferon-alpha (IFN $\alpha$ ), a pleiotropic cytokine that regulates more than 100 genes, is used in the treatment of hematologic malignancies and solid tumors. ${ }^{13,14}$ Although IFNs are effective as single agents in certain clinical pathologic entities, increasing experience with these cytokines suggests that their greatest therapeutic potential may be realized when they are used in combination with other biological response modifiers and cytotoxic or antiviral agents. ${ }^{15}$ The apoptosis event has been well characterized for several combinations with IFN $\alpha$; however, other mechanisms involved in the antitumor effectiveness of such combinations have not been explored. In fact, numerous studies in vitro and in vivo, including clinical trials, have used different IFN combinations with favorable outcomes. ${ }^{16-19}$
The double-stranded RNA-dependent protein kinase (PKR), induced by IFN type I, was initially identified as an innate immune antiviral protein..$^{20,21}$ Since then, PKR has been linked to normal cell growth and differentiation, inflammation, cytokine signaling, and apoptosis, and is involved in the antiviral and antitumor activity of IFNs cytokines. ${ }^{21}$ It has been recently suggested the major role of PKR in the induction of apoptosis by several chemotherapeutic drugs such as etoposide, doxorubicin and 5-fluorouracil, ${ }^{22-24}$ with a potential clinical use in the future.

The aims of this work were to investigate the mechanisms by which bozepinib induces apoptosis in breast and colon cancer cells and to explore the activation of the proapoptotic proteins, tumor suppressor $\mathrm{p} 53$ and IFN-induced kinase PKR. In order to improve the antitumor efficacy of bozepinib, we analyzed the synergistic effect of a bozepinib/IFN $\alpha$ combination in breast and colon cancer cells and explored the mechanisms involved in the effectiveness of this combination. Our results show that PKR, but not p53, is involved in the apoptosis induced by bozepinib used alone and in combination with IFN $\alpha$. In addition, we determined that bozepinib is able to induce other antitumor effects, including senescence and autophagy, which are strongly improved by using the IFN $\alpha$ combination.

\section{Materials and methods Cells and reagents}

A human breast MCF-7 cell line (ECACC: 86012803) and human colon cancer RKO (ATCC: CRL-2577) and HCT116 (ECACC: 91091005) cell lines were provided by the Cell Bank of the University of Granada (Granada, Spain). $\mathrm{PKR}^{+/+}$and $\mathrm{PKR}^{-/-}$mouse embryonic fibroblasts ${ }^{25}$ and human colon HCT-116 p53 $3^{+/+}$and $\mathrm{p} 53^{-/-}$cells ${ }^{26}$ were kindly provided by M Esteban (National Center of Biotechnology, Madrid, Spain) and B Vogelstein (Johns Hopkins Oncology Center, Baltimore, MD, USA), respectively. PKR was knocked down by RNA interference using shRNA-PKR as described previously. ${ }^{24}$ The cells were maintained in Dulbecco's Modified Eagle's Medium supplemented with 10\% fetal bovine serum, $1 \%$ penicillin-streptomycin, and $1 \%$ nonessential amino acid solution. Exponentially growing cells were used for all experiments. Bozepinib (Figure 1A) was synthesized as previously described, ${ }^{4}$ dissolved in dimethyl sulfoxide, and stored at $-20^{\circ} \mathrm{C}$. For each experiment, the stock solutions were further diluted in medium to obtain the desired concentrations. Human IFN $\alpha 2 b$ (Intron $A^{\circledR}$ ) was obtained from Schering-Plough (Union, NJ, USA) and mouse IFN $\alpha$ was sourced from Peprotech (Rocky Hill, NJ, USA). 
A<smiles></smiles>

B
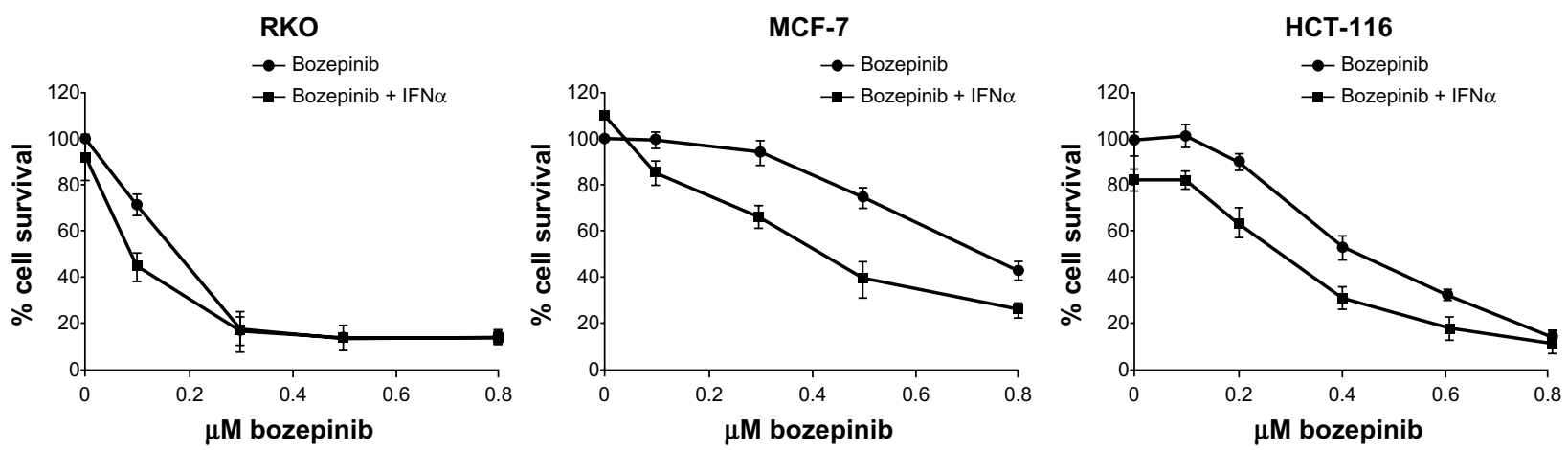

Figure I Cytotoxic effect of bozepinib and combined bozepinib/IFN $\alpha$ therapy. (A) Chemical structure of bozepinib. (B) MCF-7, HCT-II6, and RKO cell lines treated with increasing amounts of bozepinib alone (circle) or in combination with $50 \mathrm{IU} / \mathrm{mL}$ IFN $\alpha$ (square) for 6 days as described in the Materials and methods section. Cell lines have been defined in material and methods section. The curve for cell survival is represented as a percentage compared to mock-treated cells. Values shown represent the mean of triplicate determinations calculated from a single experiment. Experiments were repeated at least three times.

Abbreviation: IFN $\alpha$, interferon-alpha.

Z-VAD-FMK, a pan-caspase inhibitor, was provided by Santa Cruz Biotechnology (Santa Cruz, CA, USA) and chloroquine was obtained from Sigma-Aldrich (St Louis, MO, USA).

\section{Cell survival assay}

The effect of bozepinib on cell viability was assessed using the sulforhodamine-B colorimetric assay. Aliquots of cell suspension $\left(5 \times 10^{3}\right.$ cells/well $)$ were seeded onto 12 -well plates and incubated for 24 hours. The cells were then treated with different concentrations of bozepinib in culture medium. Three days later, the wells were aspirated, fresh medium and treatment was added, and the cells were maintained for a further 3 days. Thereafter, the cells were processed as previously described, ${ }^{27}$ using a Titertek Multiscan apparatus (Flow Laboratories, Irvine, UK) at $492 \mathrm{~nm}$. We evaluated the linearity of the sulforhodamine-B assay with the cell number for each cell stock before each cell growth experiment. The $\mathrm{IC}_{50}$ values were calculated by linear interpolation from semilogarithmic dose-response curves. To analyze the synergistic effect of addition of IFN $\alpha$, cell viability was assayed as described above, treating cells with different concentrations of bozepinib in combination with IFN $\alpha(50 \mathrm{IU} / \mathrm{mL})$. All experiments were plated in triplicate wells and carried out at least twice.

\section{Apoptosis analysis}

Cells were plated in six-well plates and maintained in an incubator overnight. The cells were then treated for 48 hours with bozepinib alone or in combination with IFN $\alpha$ (500 IU/mL). IFN $\alpha$ was added 8 hours before treatment with bozepinib. After 48 hours, the cells were trypsinized and analyzed using an Annexin V-fluorescein isothiocyanate detection kit (eBioscience Inc., San Diego, CA, USA). The samples were immediately processed using a FACSAria III flow cytometer (Becton Dickinson, BD Biosciences, Franklin Lakes, NJ, USA) from the service of the Scientific Instrumental Center (University of Granada).

\section{Cell viability assay based on the metabolic cell activity}

Cells in the exponential growth phase were plated on 96-well plates $\left(5 \times 10^{3}\right.$ cells/well $)$ and maintained in the incubator overnight. On the following day, the cells were 
treated with dimethyl sulfoxide (control), $5 \mu \mathrm{M}$ bozepinib, $500 \mathrm{IU} / \mathrm{mL}$ IFN $\alpha$, or both concentrations of the bozepinib/ IFN $\alpha$ combination. The cells were treated, or not, 2 hours before with $25 \mu \mathrm{M}$ of the pan-caspase inhibitor Z-VAD-FMK or $20 \mu \mathrm{M}$ chloroquine. After 48 hours, cell viability was measured using a sensitive colorimetric assay, ie, the Cell Counting Kit-8 (Dojindo Laboratories, Kumamoto, Japan), following the manufacturer's instructions. The Cell Counting Kit-8 is based on use of tetrazolium salt that is reduced to formazan dye in the presence of living cells. The microplate was read using a $450 \mathrm{~nm}$ filter.

\section{Cell cycle analysis}

Cells in the exponential growth phase were plated on six-well plates $\left(5 \times 10^{4}\right.$ cells/well $)$ and maintained in the incubator overnight. On the following day, the cells were treated with dimethyl sulfoxide (control), $5 \mu \mathrm{M}$ bozepinib, $500 \mathrm{IU} / \mathrm{mL}$ IFN $\alpha$, or with both concentrations of the bozepinib/IFN $\alpha$ combination for 7 days. The cells were harvested, washed twice with phosphate-buffered saline, and fixed in $70 \%$ ( vol/vol) cold ethanol for up to 1 week. Next, the cells were centrifuged, and the pellet was washed once with phosphatebuffered saline and resuspended in $250 \mu \mathrm{L}$ of propidium iodide solution $(100 \mu \mathrm{L} / \mathrm{mL}$ RNAse, $40 \mu \mathrm{L} / \mathrm{mL}$ propidium iodide in phosphate-buffered saline) for 30 minutes in the dark at $37^{\circ} \mathrm{C}$. The samples were immediately analyzed using a FACScan flow cytometer from the Scientific Instrumental Centre (University of Granada).

\section{Western blot analysis}

The cells were plated on six-well plates in their respective medium. After treatment, the medium was removed and the cells were lysed in Laemmli buffer. The protein sample was subjected to electrophoresis, transferred onto nitrocellulose membranes (Bio-Rad, Hercules, CA, USA), and blocked in phosphate-buffered saline containing 5\% nonfat dry milk for 1 hour at room temperature. Primary antibodies used included a polyclonal antibody to total human PKR (Santa Cruz Biotechnology), a polyclonal antibody to phospho-PKR (Thr 451, Sigma-Aldrich), a polyclonal antibody to phospho-eIF $2 \alpha$ (Ser 51, Invitrogen, Carlsbad, CA, USA), a polyclonal antibody to phospho-p53 (Ser 15, 92845, Cell Signaling Technology, Beverly, MA, USA), and a monoclonal antibody to $\beta$-actin (Sigma-Aldrich, A2228). Secondary antibodies used included anti-rabbit immunoglobulin (Ig)G peroxidase conjugate (Sigma-Aldrich, A0545) and anti-mouse IgG peroxidase conjugate (Sigma-Aldrich, A9044). Bands were visualized using an enhanced chemiluminescent system (Amersham Pharmacia Biotech, Little Chalfont, UK) and a Kodak detector image.

\section{Autophagy-related assay}

The cells were plated on cover slips and transfected with pCMV-GFP-LC3 plasmid and pCMV-GFP control plasmid using Lipofectamine ${ }^{\text {TM }} 2000$ (Invitrogen). At 24 hours posttransfection, the cells were mock-treated (using a similar volume of dimethyl sulfoxide) or treated with $5 \mu \mathrm{M}$ bozepinib, $500 \mathrm{IU} / \mathrm{mL}$ IFN $\alpha$, or both concentrations of the bozepinib/ IFN $\alpha$ combination over 48 hours. After treatment, the cells were washed with phosphate-buffered saline and fixed with 4\% paraformaldehyde. Images were obtained using a Radiance 2100 confocal laser microscope (Bio-Rad).

\section{Transmission electron microscopy}

The cells were mock-treated (using a similar volume of dimethyl sulfoxide) or treated with $5 \mu \mathrm{M}$ bozepinib, $500 \mathrm{IU} / \mathrm{mL}$ IFN $\alpha$, or both concentrations of the bozepinib/IFN $\alpha$ combination over 48 hours. After treatment, the cells were washed three times with phosphate-buffered saline and then fixed with $0.5 \mathrm{~mL}$ of ice-cold glutaraldehyde $(2.5 \%$ in $0.1 \mathrm{~mol} / \mathrm{L}$ cacodylate buffer, $\mathrm{pH} 7.4$ ) at $4^{\circ} \mathrm{C}$ overnight. After washing, the cells were fixed in $1 \% \mathrm{OsO}_{4}$ and embedded in Poly/Bed ${ }^{\circledR}$ resin (Polysciences Inc., Warrington, PA, USA). The ultrathin sections were doubly stained with uranyl acetate and lead citrate and analyzed by high resolution transmission electron microscopy (CM20; Philips, Eindhoven, the Netherlands).

\section{Beta-galactosidase staining}

Cells were plated on six-well plates in their respective medium. After 7 days of treatment, the medium was removed and the cells were fixed and stained using the Senescence $\beta$-Galactosidase Staining Kit (Cell Signaling Technology) according to the manufacturer's protocol following overnight incubation at $37^{\circ} \mathrm{C}$ in $\mathrm{pH} 6.0$ buffer. Senescent cells were observed by positive staining of a blue color and were photographed under a $10 \times$ objective.

\section{Statistical analysis}

All data are presented as the mean \pm standard deviation. Differences between groups were analyzed for statistical significance using the two-tailed Student's $t$-test. $P<0.05$ was accepted as the statistical significance level.

\section{Results \\ Interferon enhances cytotoxicity of bozepinib in colon and breast cancer cells by increasing apoptotic cell death}

We have previously described the antitumor effect of bozepinib in an MCF-7 breast cancer cell line, ${ }^{4,5}$ and the antitumor and 
antiproliferative effects of IFN $\alpha$ are well characterized in cancer cells. ${ }^{21,24}$ In order to analyze if bozepinib also has a cytotoxic effect on colon cancer cells, we determined the IC50 values in several cancer cell lines. HCT-116 and RKO colon cancer cell lines were more sensitive to the cytotoxic effect of bozepinib, showing lower $\mathrm{IC}_{50}$ values than the MCF-7 breast cancer cell line (Table 1). Moreover, we investigated whether addition of a low dose $(50 \mathrm{IU} / \mathrm{mL})$ of IFN $\alpha$ was able to improve the cytotoxic effect of bozepinib. This low dose by itself was not able to induce a significant antiproliferative effect in the RKO and MCF-7 cancer cell lines, but slightly affected the viability of HCT-116 cells (Figure 1B). However, both compounds synergistically induced death of the cancer cell lines analyzed (Figure 1B), and consequently, the $\mathrm{IC}_{50}$ for bozepinib was reduced when combined with IFN $\alpha$ (Table 1).

In order to determine if the effectiveness of the bozepinib/ IFN $\alpha$ combination is due in part to an improvement in the apoptosis phenomenon, we treated MCF-7, HCT-116, and RKO cell lines with bozepinib alone or in combination with $500 \mathrm{IU} / \mathrm{mL}$ IFN $\alpha$. As shown in Figure 2, the apoptosis induced by bozepinib at 48 hours was significantly increased when IFN $\alpha$ was added in all the cell lines analyzed (Figure 2).

\section{PKR but not $\mathrm{p} 53$ is involved in bozepinib-induced apoptosis and effectiveness of bozepinib/IFN $\alpha$}

We first analyzed PKR phosphorylation and its natural substrate, eIF $2 \alpha$, in the MCF-7 and HCT-116 cell lines. Treatment with bozepinib induced PKR and eIF2 $\alpha$ phosphorylation in both tumor cell lines. Importantly, it was also observed that there was an increase in PKR levels after treatment with bozepinib that was more evident in the HCT-116 cell line, in which the basal PKR level (total and phosphorylated) was lower than that in MCF-7 cells. In contrast, levels of p53 and phospho-p53 were not affected during treatment with bozepinib in either cell line (Figure 3A).

Table I Antiproliferative effects of bozepinib and bozepinip + IFN $\alpha$ on several cell lines

\begin{tabular}{lll}
\hline Cell line & $I_{50}(\mu \mathrm{M})^{\mathrm{a}}$ & \\
\cline { 2 - 3 } & Bozepinib & Bozepinib + IFN $\alpha$ \\
\hline RKO & $0.13 \pm 0.01$ & $0.09 \pm 0.01$ \\
MCF-7 & $0.78 \pm 0.06$ & $0.44 \pm 0.03$ \\
HCT-II6 & $0.48 \pm 0.08$ & $0.31 \pm 0.02$ \\
MEFsPKR ${ }^{+/+}$ & $1.12 \pm 0.18$ & $0.89 \pm 0.08$ \\
MEFsPKR $^{-/-}$ & $1.74 \pm 0.28$ & $1.77 \pm 0.18$ \\
\hline
\end{tabular}

Notes: ${ }^{a} A l l$ experiments were conducted in triplicate and gave similar results. The data are the mean \pm standard error of the mean of three independent determinations. $\mathrm{IC}_{50}$ was determined after 6 days of treatment.

Abbreviations: IFN $\alpha$, interferon-alpha; $\mathrm{IC}_{50}, 50 \%$ inhibitory concentration.
Next, we analyzed the contribution of PKR and p53 to the apoptosis induced by bozepinib. Further, because PKR is an IFN-induced protein that is involved in most of the antiviral and antitumor effects of this cytokine, ${ }^{21}$ we also analyzed the effect of absence of PKR on the effectiveness of the bozepinib/IFN $\alpha$ combination. Bozepinib and IFN $\alpha$ were independently able to induce important levels of apoptosis in $\mathrm{PKR}^{+/+}$mouse embryonic fibroblasts that was enhanced when the two compounds were combined. However, low levels of apoptosis were induced in the absence of the PKR protein in $\mathrm{PKR}^{-/}$mouse embryonic fibroblasts, even when bozepinib and IFN $\alpha$ were combined (Figure 3B, upper panel).

To demonstrate the role of PKR in the cytotoxic effect of bozepinib and the bozepinib/IFN $\alpha$ combination, we also analyzed cell survival in $\mathrm{PKR}^{+/+}$and $\mathrm{PKR}^{-/-}$mouse embryonic fibroblasts treated with increasing amounts of bozepinib, and the cytotoxic effect of bozepinib was found to be higher in $\mathrm{PKR}^{+/+}$mouse embryonic fibroblasts in comparison with $\mathrm{PKR}^{-/-}$mouse embryonic fibroblasts (Figure 3B, lower panel, and Table 1). Further, our results showed that whereas viability was significantly reduced in $\mathrm{PKR}^{+/+}$mouse embryonic fibroblasts when IFN $\alpha$ was added to bozepinib, cell viability was not affected by the bozepinib/IFN $\alpha$ combination in $\mathrm{PKR}^{-/-}$mouse embryonic fibroblasts.

Although p53 modification after treatment with bozepinib was not detected by Western blotting (Figure 3A), we went on to analyze the effect of bozepinib, IFN $\alpha$, and the bozepinib/ IFN $\alpha$ combination in the presence or absence of $\mathrm{p} 53$ protein in wild-type HCT-116 and HCT-116-p53 knockout cells (Figure 3C). Levels of apoptosis after the treatments were similar in both cell lines; however, when PKR was knocked down by RNA interference using shRNA-PKR, apoptosis was significantly reduced (Figure 3C). Taken together, these results suggest that, in part, PKR but not p53 contributes to the response of cancer cells to the bozepinib and bozepinib/ IFN $\alpha$ combination.

\section{Autophagy is involved in the synergistic effect of bozepinib/IFN $\alpha$}

We analyzed the ability of bozepinib to induce autophagy as well as regulation of this process by IFN $\alpha$ in the MCF-7 cell line, which is deficient in caspase 3 activation. ${ }^{28}$ Despite the low level of endogenous LC3 protein, LC3-II levels were weakly detected 48 hours after treatment with bozepinib and were more evident when IFN $\alpha$ was added (Figure 4A). Confocal microscopy was used to analyze the redistribution 
A
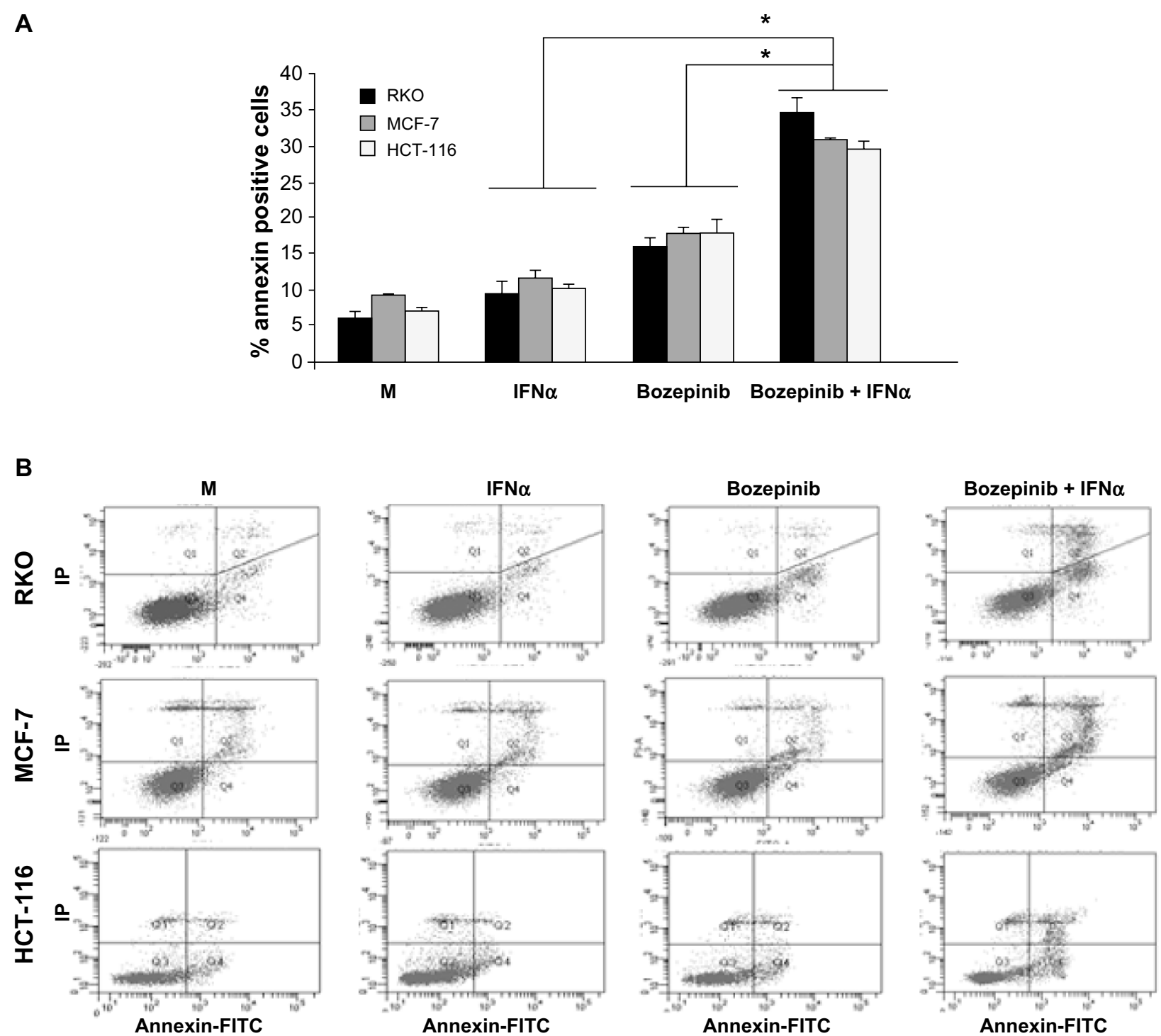

Annexin-FITC

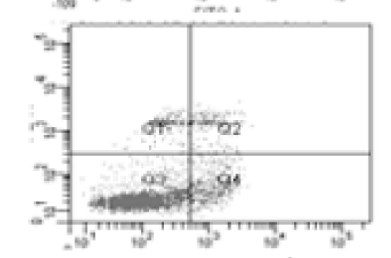

Annexin-FITC

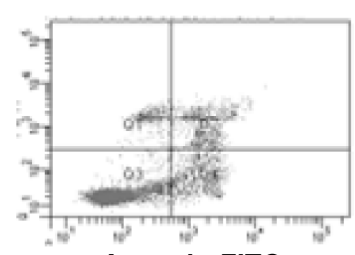

Figure 2 Apoptosis is enhanced by combination of bozepinib and IFN $\alpha$. MCF-7, HCT-1 I6, and RKO cell lines were mock-treated or treated with $5 \mu$ M bozepinib, 500 IU/mL IFN $\alpha$, or the bozepinib/IFN $\alpha$ combination for 48 hours. Treated cells were then trypsinized and analyzed by flow cytometry using an Annexin V-fluorescein isothiocyanate detection kit. (A) Data are expressed as the mean \pm standard error of the mean of three independent experiments. * $* 0.05$ ( $t$-test). (B) Representative images from flow cytometry analysis.

Abbreviations: FITC, fluorescein isothiocyanate; IFN $\alpha$, interferon-alpha; M, mock treated cells.

of LC3 protein into the autophagosomes of MCF-7 cells transfected with the pCMV-GFP-LC3 vector and the pCMVGFP control vector, and the cells were then mock-treated or treated with bozepinib, IFN $\alpha$, or the bozepinib/IFN $\alpha$ combination. As shown in Figure 4B, 48 hours post-treatment, the mock-treated cells displayed diffuse staining. However, a speckled fluorescent staining pattern was detected in almost all cells analyzed after treatment with bozepinib/IFN $\alpha$, indicating redistribution of LC3 to autophagosomes. The speckled fluorescent stain was less pronounced after treatment with bozepinib alone or IFN $\alpha$ alone, and was detected in less than half of the cells analyzed (Figure 4B). Cells expressing the control vector pCMV-GFP displayed diffuse staining, even in the presence of treatment with bozepinib/ IFN $\alpha$ (Figure 4B).

Moreover, we analyzed cell morphology using transmission electron microscopy 48 hours post-treatment. The most spectacular morphologic effects were observed when IFN $\alpha$ was combined with bozepinib. As shown in Figure $4 \mathrm{C}$, autophagic vacuoles surrounded by a doublelayered membrane and containing cytoplasmic constituents were observed after treatment with bozepinib/IFN $\alpha$. Similar to the MCF-7 cell line, colon cancer HCT-116 cells showed autophagic vacuoles after the treatments, and this was also observed in the transmission electron microscopy images (Figure 4C). 


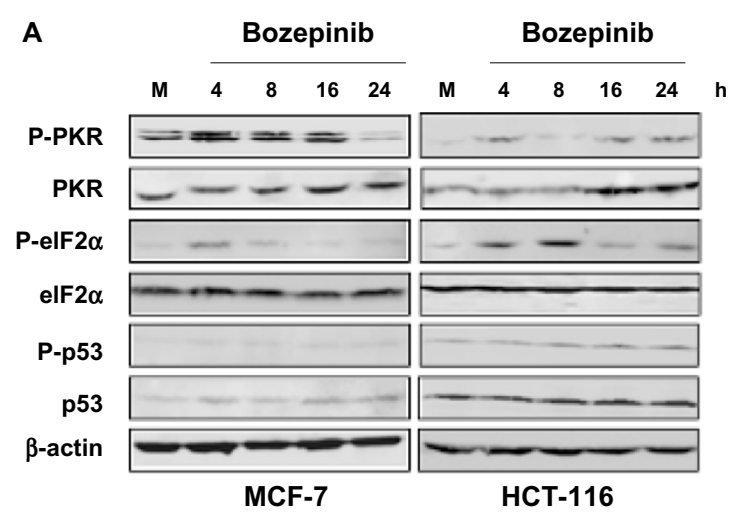

B
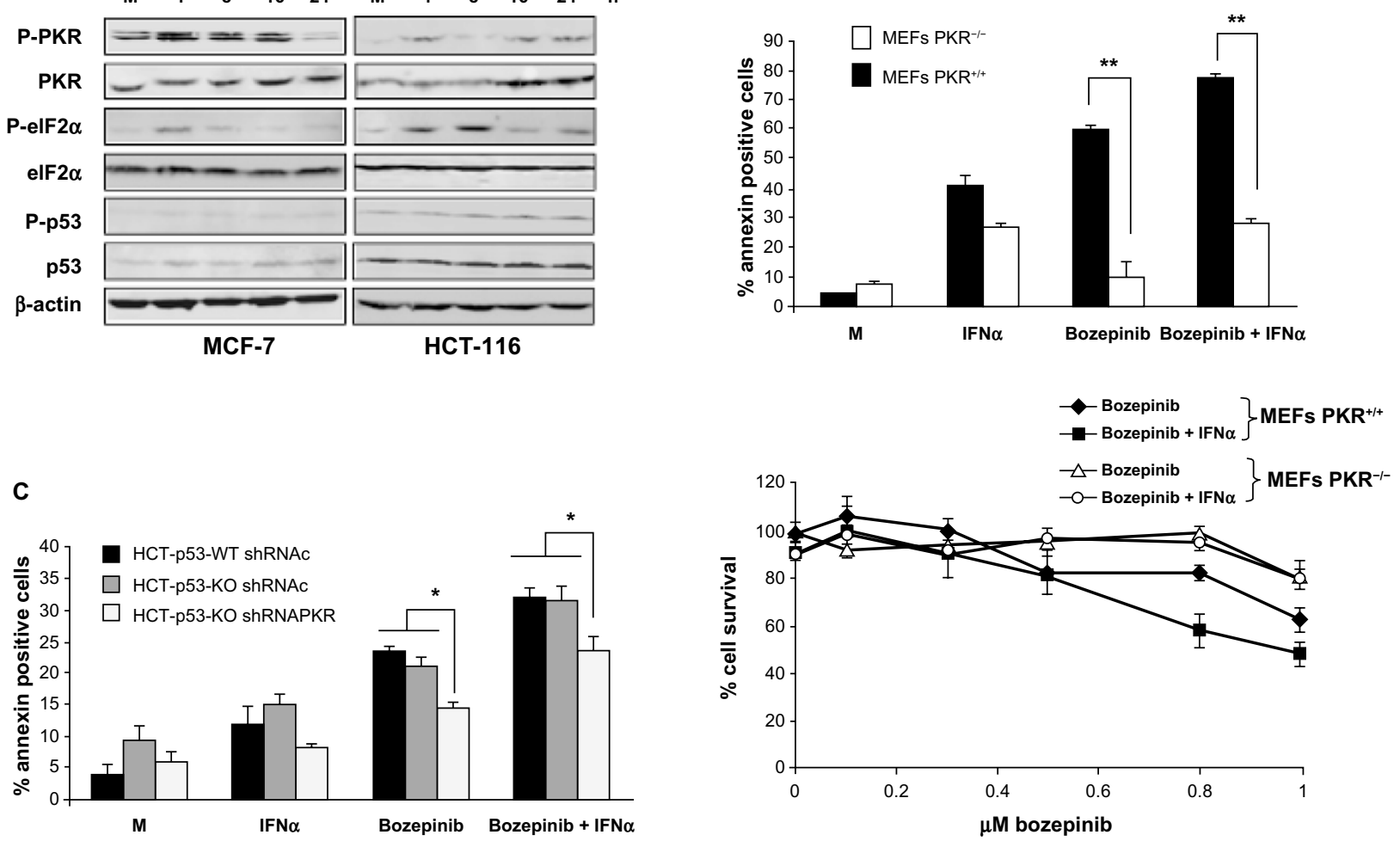

Figure 3 PKR and p53 activation during bozepinib treatment and its involvement in apoptosis and cell viability on bozepinib, IFN $\alpha$, and the bozepinib//FN $\alpha$ combination. (A) MCF-7 and HCT-1 I6 cell lines were mock-treated or treated with $5 \mu \mathrm{M}$ bozepinib for 4, 8, 16, and 24 hours. Total proteins were extracted for immunoblot analysis using anti-phospho PKR, anti-whole PKR, anti-phospho elF2 $\alpha$, anti-whole elF2 $\alpha$, anti-phospho p53, anti-whole p53, and anti- $\beta$-actin antibodies. (B) PKR ${ }^{++}$and PKR ${ }^{--}$mouse embryonic fibroblasts were mock-treated or treated with $2.5 \mu \mathrm{M}$ bozepinib, $500 \mathrm{IU} / \mathrm{mL}$ IFN $\alpha$, or the bozepinib/IFN $\alpha$ combination over 48 hours. ***P<0.0I, by $t$-test (upper panel). Subsequently, the cells were trypsinized and analyzed by flow cytometry for Annexin $\vee$ positive determination. Cells were treated with increasing amounts of bozepinib alone or in combination with $50 \mathrm{IU} / \mathrm{mL}$ of mouse IFN $\alpha$ over 6 days as described in the Materials and methods section. The curve for cell survival was represented as the percentage compared to mock-treated cells. Values shown represent the mean of triplicate determinations calculated from a single experiment. Experiments were repeated at least three times (lower panel). (C) A wild-type HCT-116 p53 cell line and an HCT-116 p53 knockout cell line expressing short hairpin RNAs targeting PKR or expressing a control short hairpin RNA were mock-treated or treated with $5 \mu \mathrm{M}$ bozepinib, $500 \mathrm{IU} / \mathrm{mL}$ human IFN $\alpha$, or a combination of bozepinib/IFN $\alpha$ for 48 hours. $* P<0.05$ (t-test).

Abbreviations: IFN $\alpha$, interferon-alpha; MEFs, mouse embryonic fibroblasts; shRNAc, control short hairpin RNA; PKR, RNA-dependent protein kinase; h, hours; M, mock treated cells; shRNAPKR, PKR short hairpin RNA.

In order to analyze involvement of the autophagy process induced by the bozepinib/IFN $\alpha$ combination in cell viability, MCF-7 cells were treated with the autophagy inhibitor chloroquine and the caspase-3 inhibitor Z-VAD 2 hours before treatment with bozepinib, IFN $\alpha$, or bozepinib/ IFN $\alpha$ (Figure 4D). Whereas Z-VAD did not affect cell death induced by either bozepinib alone or the bozepinib/IFN $\alpha$ combination, viability after bozepinib/IFN $\alpha$ treatment was significantly higher in cells pretreated with chloroquine. Treatment with chloroquine caused accumulation of LC3II, that has been suggested to be the result of chloroquineinduced inhibition of fusion between autophagosome and lysosomes, ${ }^{29,30}$ and was more evident after treatment with bozepinib/IFN $\alpha$ (Figure 4D).

These results indicate that bozepinib is able to induce the autophagy process in cancer cells that is clearly evidenced when it is combined with the IFN $\alpha$ cytokine, and suggest the contribution of autophagy to the cell death induced by the combination of bozepinib/IFN $\alpha$.

\section{IFN $\alpha$ enhances ability of bozepinib to induce lysosomal senescence- associated ß-galactosidase activity}

During long-term treatment with bozepinib and the bozepinib/IFN $\alpha$ combination at low doses, we observed that a minority population remained in all the cell lines analyzed, but was more evident in the MCF-7 cell line. In order to characterize this population, we investigated B-galactosidase activity and the cell cycle in MCF-7 cells. B-galactosidase activity was detected in the residual surviving population after 7 days of treatment with bozepinib, as shown in Figure 5A. However, although this population 
A

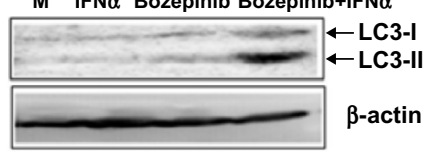

B

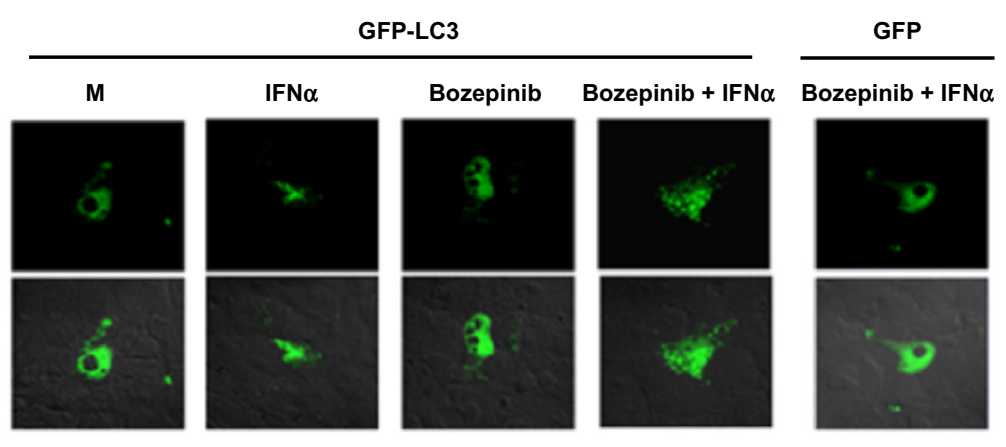

C

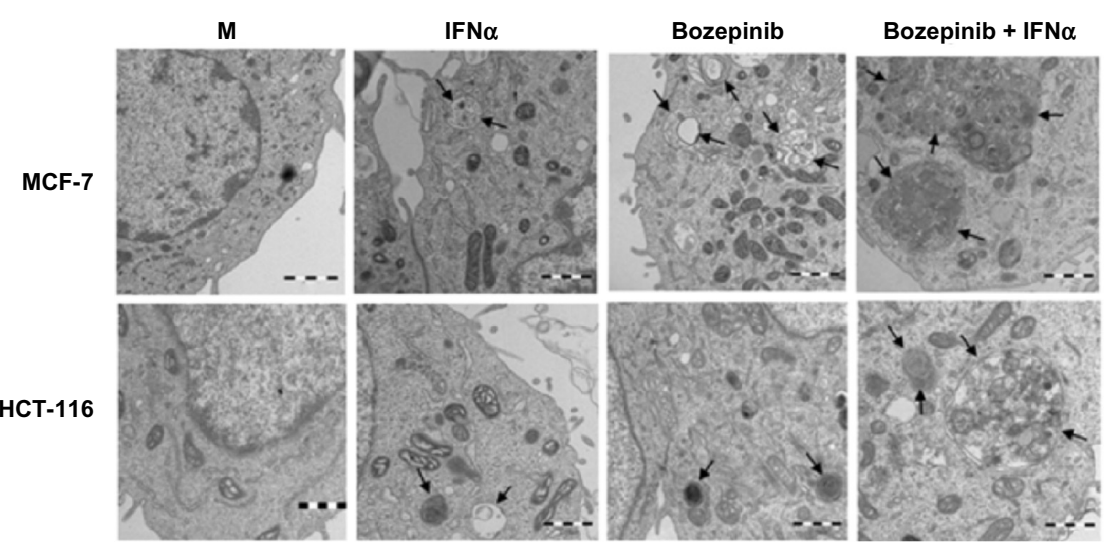

D

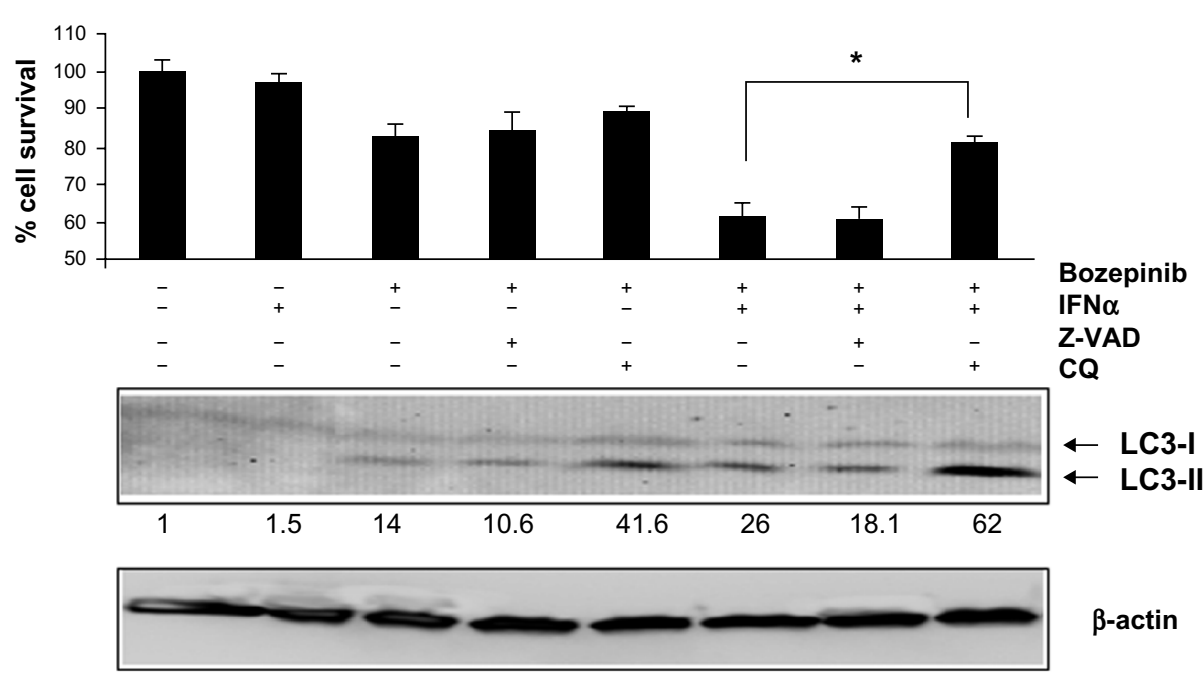

Figure 4 Bozepinib induced LC3-autophagosome formation that was strongly enhanced when combined with IFN $\alpha$. (A) MCF-7 cells were mock-treated or treated with $5 \mu \mathrm{M}$ bozepinib, $500 \mathrm{IU} / \mathrm{mL}$ human IFN $\alpha$, or a combination of bozepinib/IFN $\alpha$ for 48 hours. Total proteins were extracted for immunoblot analysis using anti-LC3 and anti$\beta$-actin antibodies. (B) MCF-7 cells were plated on cover slips supported in six-well plates and transfected with $5 \mu \mathrm{g}$ of GFP-LC3 or GFP-control plasmids as described in the Materials and methods section. After 24 hours, the cells were treated with $5 \mu$ M bozepinib, $500 \mathrm{IU} / \mathrm{mL}$ human IFN $\alpha$, or a combination of bozepinib/IFN $\alpha$ for 48 hours. Cells were fixed and visualized using a Radiance 2000 confocal microscope. (C) MCF-7 and HCT-II 6 cells were mock-treated or treated with $5 \mu$ M bozepinib, 500 IU/mL human IFN $\alpha$, or a combination of bozepinib/IFN $\alpha$ for 48 hours. Cells were fixed and prepared for visualization by transmission electron microscopy as described in the Materials and methods section. Transmission electron microscopy images show that the treated cells included typical autophagolysosomes (arrows) containing organelles and lamellar structures. (D) MCF-7 cells were treated with $20 \mu \mathrm{M}$ of chloroquine or $25 \mu \mathrm{M}$ of Z-VAD inhibitors 2 hours before $5 \mu \mathrm{M}$ bozepinib, 500 IU/mL IFN $\alpha$, or a combination of bozepinib/IFN $\alpha$. After 48 hours, the cells were treated with a Cell Counting Kit-8, measured at $450 \mathrm{~nm}$ optical density and represented as described in the Materials and methods section. Total proteins were extracted for immunoblot analysis using anti-LC3 and anti- $\beta$-actin antibodies. $* P<0.05$ ( $t$-test). Western blot signals were quantified using Image J software, and relative $\beta$-actin-normalized values were assigned in reference to nontreated cells (value I).

Abbreviations: $\mathrm{CQ}$, chloroquine; IFN $\alpha$, interferon-alpha; $M$, mock treated cells. 

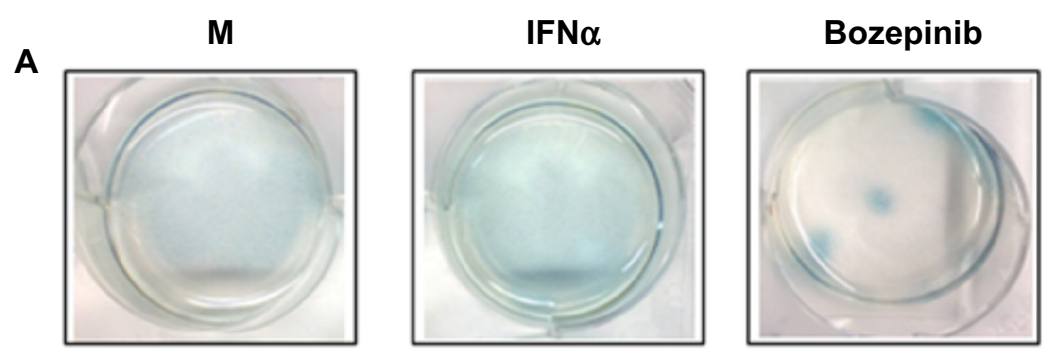

Bozepinib + IFN $\alpha$
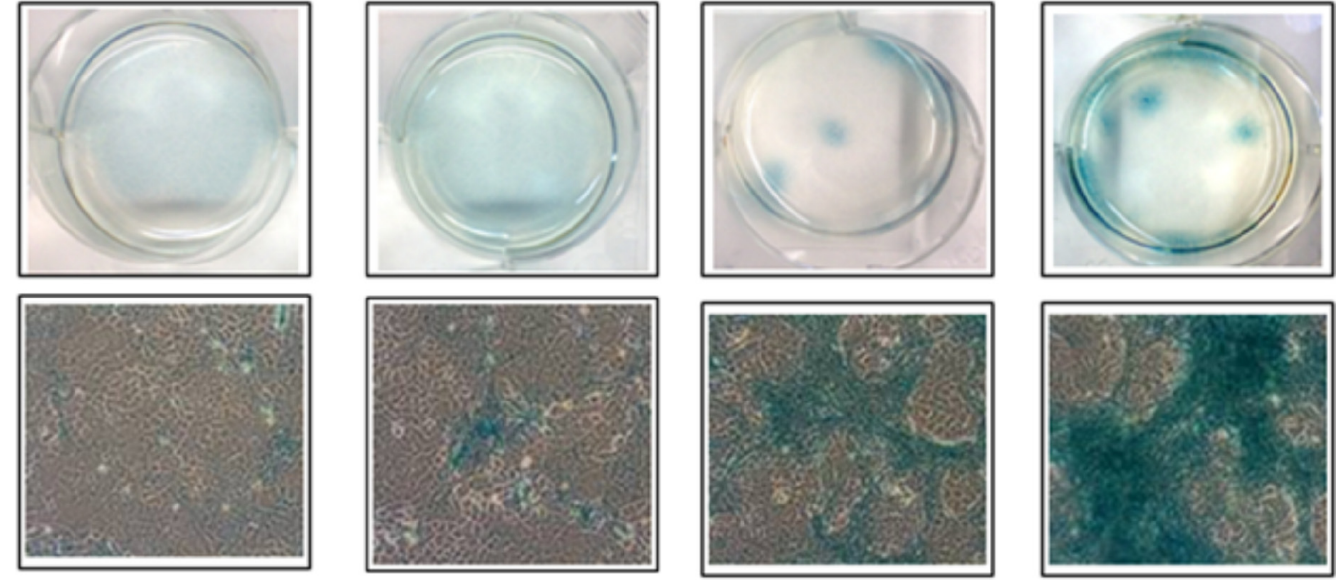

M

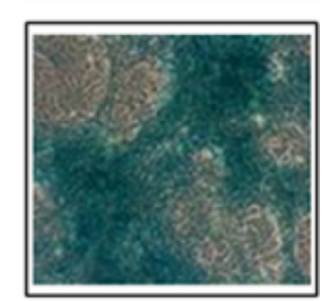

B
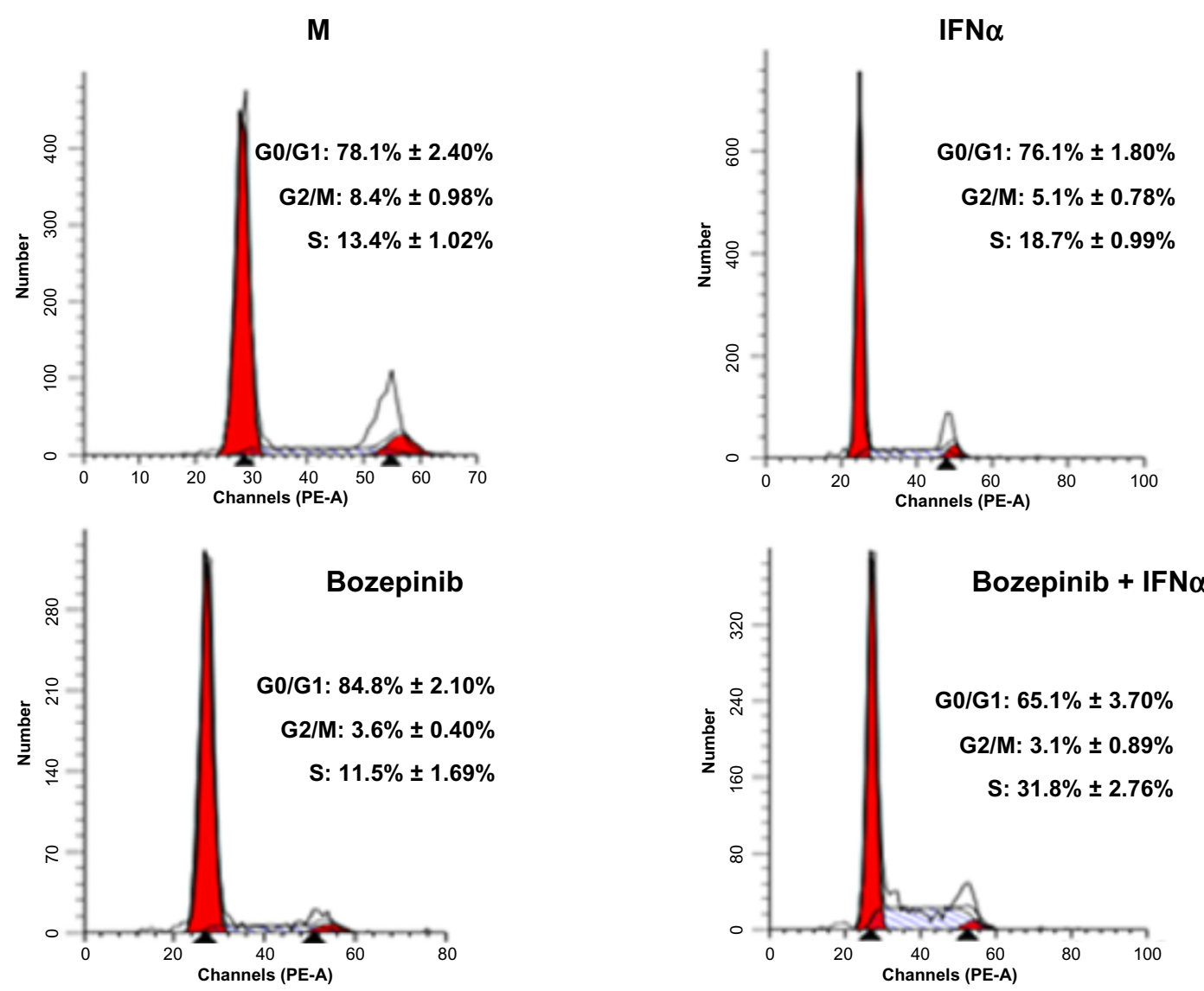

Figure 5 IFN $\alpha$ enhanced the ability of bozepinib to induce B-galactosidase activity. MCF-7 cells were mock-treated or treated with $2.5 \mu M$ of bozepinib, 500 IU/mL human IFN $\alpha$, or a combination of bozepinib/IFN $\alpha$ over 7 days. (A) Cells were fixed and stained using the Senescence $\beta$-Galactosidase Staining Kit as described in the Materials and methods section and photographed under a $10 \times$ objective with a microscope (Leica) using visible light (lower panel) and the corresponding six wells were photographed under a $I \times$ objective using a standard camera (upper panel). (B) Cells were fixed and analyzed by flow cytometry after staining with propidium iodide. Values represent the mean of triplicate determinations calculated from a single experiment. Experiments were repeated at least three times.

Abbreviations: IFN $\alpha$, interferon-alpha; M, mock treated cells.

was minor after 7 days of treatment with bozepinib/IFN $\alpha$, $\beta$-galactosidase activity was more evident. Moreover, the percentage of cells arrested in S phase after treatment with bozepinib/IFN $\alpha$ was around $30 \%$, whereas the mocktreated cells and those treated with bozepinib alone showed
$11 \%-13 \%$ in S phase (Figure 5B) after 7 days of treatment. Therefore, both bozepinib and IFN $\alpha$ were able to induce senescence in the residual surviving population, and this was more evident when bozepinib and IFN $\alpha$ were used in combination. 


\section{Discussion}

Purine derivatives have shown potent antitumor activity and represent a new generation of anticancer drugs. ${ }^{4}$ We have previously reported that bozepinib has an $\mathrm{IC}_{50}$ value ten times smaller than that of 5-fluorouracil in MCF-7 breast cancer cells. Moreover, bozepinib induces a considerable level of cell death by apoptosis via a mechanism that is still unknown. Bozepinib does not trigger acute toxicity in mice after 2 weeks of treatment. ${ }^{5}$ In the present study, we demonstrated that bozepinib also has antitumor activity in colon cancer cells, with $\mathrm{IC}_{50}$ values lower than those described for breast cancer cells (Figure 1 and Table 1), suggesting great potential of this synthetic drug in the treatment of cancer. In order to identify the molecular targets involved in bozepinib-mediated apoptosis, we analyzed the induction and activation of the proapoptotic proteins, PKR and tumor suppressor p53. PKR but not p53 was markedly induced and activated in breast and colon cancer cell lines during treatment with bozepinib, thereby triggering phosphorylation of eIF $2 \alpha$. It is well established that eIF $2 \alpha$ phosphorylation is correlated with translational block and consequently leads to inhibition of protein synthesis, providing the cell with an opportunity to make adaptive responses to stress that could finally trigger cell death by apoptosis. ${ }^{31}$ Analysis of the level of PKR messenger (m)RNA during treatment with bozepinib suggested that upregulation of the PKR protein was not due to a transcriptional phenomenon (data not shown), similar to what we have described for 5-fluorouracil. ${ }^{24}$ It is widely known that p53 is critical for the apoptotic response to agents that damage DNA and cause cytotoxicity, such as 5-fluorouracil, etoposide, paclitaxel, and cisplatin. ${ }^{32}$ However, loss of p53 function is frequently involved in the resistance of tumors to chemotherapeutic agents. Moreover, apoptosis can also occur in mutant p53 cell lines in response to some of these chemotherapeutic drugs, suggesting that more targets are involved in induction of apoptosis in response to chemotherapy. ${ }^{24,33,34}$ Recently, it has been shown that the PKR protein plays an important role in induction of apoptosis by doxorubicin, etoposide, and 5-fluorouracil, with both p53 and PKR being necessary for cancer cell death by apoptosis in response to chemotherapy. ${ }^{22-24}$ Curiously, this study provides the first evidence that PKR but not p53 is involved in induction of apoptosis by an antitumor purine derivative (Figure 3). In fact, the levels of apoptosis induced by bozepinib are similar in HCT-116 colon cancer cells regardless of the presence or absence of $\mathrm{p} 53$ protein (Figure 3C). However, the absence or downregulation of PKR expression in mouse embryonic fibroblast knockout cells or in human colon cancer cells expressing PKR interference significantly decreased the apoptosis induced by bozepinib (Figure 3). Since p53 is mutated in more than $50 \%$ of tumors, drugs inducing apoptosis through molecular targets different from p53 are of great clinical interest.

Drug combinations in cancer therapy that enhance efficacy have had great success in a variety of therapeutic applications. ${ }^{16}$ Our results show that bozepinib and IFN $\alpha$ act synergistically to suppress the viability of breast and colon cancer cells to a greater extent than when either agent is used alone, reducing cell viability by more than $20 \%$ in all cell lines analyzed (Figure 1B). Several studies have demonstrated that IFN $\alpha$ enhances the chemosensitivity of cancer cells to a number of drugs, mainly via improvement of apoptosis. It has recently been reported that a combination of 9-cis-retinoic acid and IFN $\alpha$ induces marked antiproliferative and proapoptotic effects in cancer cells by modulation of critical targets, such as p27 Kip1 and p21 WAF1/Cip1 proteins. ${ }^{16}$ Moreover, several in vitro and in vivo studies have demonstrated the effectiveness of a combination of IFN $\alpha$ and 5-fluorouracil, ${ }^{35}$ where p27 Kip1, Fas/FasL, and TNF-related apoptosis-inducing ligand (TRAIL) have been found to be involved in enhancement of apoptosis. In addition, we have identified PKR protein as an interesting molecular target that is key to the effectiveness of the 5-fluorouracil/IFN $\alpha$ combination. ${ }^{24}$ The present study shows that one of the mechanisms by which IFN $\alpha$ improves the cytotoxic effect of bozepinib involves enhancement of apoptosis, and that the synergistic apoptotic effect induced by the bozepinib/IFN $\alpha$ combination is affected by the absence or downregulation of PKR protein (Figure 3). In fact, the cytotoxic effect of bozepinib was higher in $\mathrm{PKR}^{+/+}$mouse embryonic fibroblasts in comparison with $\mathrm{PKR}^{-/}$mouse embryonic fibroblasts, and cell viability was significantly reduced when IFN $\alpha$ was combined with bozepinib in $\mathrm{PKR}^{+/+}$ mouse embryonic fibroblasts. In contrast, cell viability was not affected by the bozepinib/IFN $\alpha$ combination in $\mathrm{PKR}^{-/}$ mouse embryonic fibroblasts. These data suggest that PKR, in part, contributes to the effectiveness of the bozepinib/ IFN $\alpha$ combination, and therefore we hypothesize that its deregulation in tumors could affect the response of patients to combined therapies.

Given that most cancer cells show low levels of active caspases or mutations that inactivate the effectors of apoptosis, ${ }^{36}$ antitumor drugs inducing additional or alternative mechanisms of cell death are of great interest. It has been suggested that autophagy could constitute an alternative cell death pathway in cells with a disrupted apoptotic path- 
way. ${ }^{10}$ In this sense, MCF-7 cells are a good model system to study drug-induced cell death by autophagy due to their defective caspase activation. ${ }^{37,38}$ Moreover, effects other than apoptosis induced by combined IFN $\alpha$ antitumor therapies have not yet been explored. In our study, bozepinib was able to induce autophagosomes, as shown by the conversion of LC3-I to LC 3-II (Figure 4A), relocalization of the GFPLC3 protein (Figure 4B), and electron microscopic images (Figure 4C). Surprisingly, addition of IFN $\alpha$ clearly increased autophagosome levels in MCF-7 cells (Figure 4). Moreover, previous treatment with a low dose of chloroquine was able to significantly reduce the cell death induced by bozepinib/ IFN $\alpha$ (Figure 4D). Similar as described for rottlerin and etoposide, ${ }^{38,39}$ autophagy leads to cell death in response to bozepinib/IFN $\alpha$ treatment. Consistent with the inability of $\mathrm{MCF}-7$ cells to induce activation of caspase- $3,{ }^{28}$ pretreatment with the pan-caspase inhibitor Z-VAD did not affect the cell viability seen after the treatments (Figure 4D). Although it is known that autophagy is required for the production of IFN $\alpha$ by plasmacytoid dendritic cells during viral infection, ${ }^{40}$ and it has been recently shown that type I IFN induces autophagic trafficking of viral proteins of hepatitis $\mathrm{C}$ virus, ${ }^{41}$ the role of IFN $\alpha$ in the autophagy process is still unclear and knowledge is restricted to its antiviral function. Our results show, for the first time, evidence that IFN $\alpha$ is involved in the autophagy process in combination with an antitumor agent. The mechanism of action involved in this process needs to be investigated further, and might have important therapeutic implications.

Finally, we observed that during long-term treatment with even low doses of bozepinib and the bozepinib/IFN $\alpha$ combination, a minority population showing $\beta$-galactosidase activity persisted in MCF-7 cells, being once again more evident in surviving cells treated with the bozepinib/IFN $\alpha$ combination (Figure 5A). Moreover, this population showed a high percentage of cells arrested in $\mathrm{S}$ phase in comparison with cells treated or not with bozepinib or IFN $\alpha$ separately (Figure 5B). Because tumors often develop resistance to apoptosis induced by anticancer treatment, induction of senescence in tumor cells could be an alternative approach to cancer therapy, and be especially effective in the treatment of cancer cells in which apoptotic pathways are disabled. ${ }^{12}$ Although the exact mechanism by which IFN $\alpha$ regulates senescence is still under investigation, it has been suggested that IFN $\alpha$ downregulates telomerase activity along with inhibition of growth in Daudi lymphoma cells. ${ }^{42}$ It has also been suggested that overexpression of two IFN regulatory transcription factors (IRF5 and IRF7) is able to induce a senescence-related phenotype in immortal cells. ${ }^{43}$ More recently, early evidence has been reported showing that a combination of IFN $\alpha$ and a chemotherapeutic agent, vinblastine, triggers senescence; however, the authors showed this effect in endothelial cells in the context of angiogenesis within the tumor. ${ }^{44}$ Our results show that IFN $\alpha$ enhances the senescence provoked in tumor cells by bozepinib, suggesting that this cytokine could act directly in this process when combined with other antitumor drugs.

\section{Conclusion}

The development of novel anticancer drugs that are more effective and have fewer side effects in patients is an important research topic in cancer, and understanding the mechanisms involved in the antitumor effects of new compounds is necessary for their clinical application. Bozepinib is a potent antitumor agent that is able to induce apoptosis in breast and colon cancer cells. In this study, we have demonstrated that PKR but not p53 is involved in the apoptosis induced by bozepinib, which has encouraged us to explore targets for new compounds with high antitumor activity and enabling effectiveness at low doses. Given that p53 is mutated in more than $50 \%$ of tumors, drugs inducing apoptosis through molecular targets different to p53 are of great clinical interest. Moreover, our results highlight the benefit of combination chemotherapy using natural cytokines, such as IFN $\alpha$, which can potentiate the apoptosis induced by chemotherapy. IFN $\alpha$ also enhances autophagy and senescence, which are processes suggested to be of great importance, especially in tumor cells that show resistance to conventional chemotherapy. Our study increases our knowledge about the synergistic effect induced by IFN, and supports the need to explore new combinations with potent antitumor agents such as bozepinib, which can enhance the diversity of cell death outcomes, leading to more effective and less toxic chemotherapy.

\section{Acknowledgments}

We gratefully acknowledge Jaime Lazuen for providing excellent technical assistance with the cytometry studies and Manuela Expósito for statistical assistance. We also thank staff from the Experimental Surgery Research Unit, and Pablo Bueno for support with equipment. This work was supported in part by grants from the Instituto de Salud Carlos III (Fondo de Investigación Sanitaria FEDER funds, CP08/0063, PI10/02295, and PI10/00592).

\section{Disclosure}

The authors report no conflicts of interest in this work. 


\section{References}

1. Ferlay J, Shin HR, Bray F, Forman D, Mathers C, Parkin DM. Estimates of worldwide burden of cancer in 2008: GLOBOCAN 2008. Int J Cancer. 2010;127(12):2893-2917.

2. Díaz-Gavilán M, Conejo-García A, Cruz-López O, et al. Synthesis and anticancer activity of $(R, S)-9-(2,3$-dihydro-1,4-benzoxathiin-3ylmethyl)-9H-purines. ChemMedChem. 2008;3(1):127-135.

3. Díaz-Gavilán M, Gómez-Vidal JA, Entrena A, Gallo MA, Espinosa A, Campos JM. Study of the factors that control the ratio of the products between 5-fluorouracil, uracil, and tetrahydrobenzoxazepine $O, O$-acetals bearing electron-withdrawing groups on the nitrogen atom. J Org Chem. 2006;71(3):1043-1054.

4. Núñez MC, Díaz-Gavilán M, Conejo-García A, et al. Design, synthesis and anticancer activity against the MCF-7 cell line of benzo-fused 1,4-dihetero seven- and six-membered tethered pyrimidines and purines. Curr Med Chem. 2008;15(25):2614-2631.

5. López-Cara LC, Conejo-García A, Marchal JA, et al. New (RS)benzoxazepin-purines with antitumour activity: the chiral switch from $(R S)$-2,6-dichloro-9-[1-( $p$-nitrobenzenesulfonyl)-1,2,3,5-tetrahydro4,1-benzoxazepin-3-yl]-9H-purine. Eur J Med Chem. 2011;46(1): 249-258.

6. Ferri KF, Kroemer G. Organelle-specific initiation of cell death pathways. Nat Cell Biol. 2001;3(11):E255-E263.

7. de Bruin EC, Medema JP. Apoptosis and non-apoptotic deaths in cancer development and treatment response. Cancer Treat Rev. 2008;34(8): 737-749.

8. Mansilla S, Llovera L, Portugal J. Chemotherapeutic targeting of cell death pathways. Anticancer Agents Med Chem. 2012;12(3):226-238.

9. White E, Karp C, Strohecker AM, Guo Y, Mathew R. Role of autophagy in suppression of inflammation and cancer. Curr Opin Cell Biol. 2010;22(2):212-217.

10. Dalby KN, Tekedereli I, Lopez-Berestein G, Ozpolat B. Targeting the prodeath and prosurvival functions of autophagy as novel therapeutic strategies in cancer. Autophagy. 2010;6(3):322-329.

11. Hayflick L, Moorhead PS. The serial cultivation of human diploid cell strains. Exp Cell Res. 1961;25(3):585-621.

12. Kong Y, Cui H, Ramkumar C, Zhang H. Regulation of senescence in cancer and aging. J Aging Res. 2011;2011:963172.

13. Hasselbalch HC. Interferon alpha 2 in the treatment of hematological malignancies. Status and perspectives. Curr Drug Targets. 2011;12(3): 387-391.

14. Tarhini AA, Gogas H, Kirkwood JM. IFN-alpha in the treatment of melanoma. J Immunol. 2012;189(8):3789-3793.

15. Kirkwood J. Cancer immunotherapy: the interferon-alpha experience. Semin Oncol. 2002;29(3 Suppl 7):18-26.

16. Dal Col J, Mastorci K, Fae DA, et al. Retinoic acid/alpha-interferon combination inhibits growth and promotes apoptosis in mantle cell lymphoma through Akt-dependent modulation of critical targets. Cancer Res. 2012;72(7):1825-1835.

17. Tarhini AA, Cherian J, Moschos SJ, et al. Safety and efficacy of combination immunotherapy with interferon alfa- $2 \mathrm{~b}$ and tremelimumab in patients with stage IV melanoma. J Clin Oncol. 2012;30(3):322-328.

18. Simonsson B, Hjorth-Hansen H, Bjerrum OW, Porkka K. Interferon alpha for treatment of chronic myeloid leukemia. Curr Drug Targets. 2011;12(3):420-428.

19. Negrier S, Gravis G, Perol D, et al. Temsirolimus and bevacizumab, or sunitinib, or interferon alfa and bevacizumab for patients with advanced renal cell carcinoma (TORAVA): a randomised phase 2 trial. Lancet Oncol. 2011;12(7):673-680.

20. Esteban M, Kerr IM. The synthesis of encephalomyocarditis virus polypeptides in infected L-cells and cell-free systems. Eur J Biochem. 1974;45(2):567-576.

21. García MA, Gil J, Ventoso I, et al. Impact of protein kinase PKR in cell biology: from antiviral to antiproliferative action. Microbiol Mol Biol Rev. 2006;70(4):1032-1060.
22. Yoon CH, Lee ES, Lim DS, Bae YS. PKR, a p53 target gene, plays a crucial role in the tumor-suppressor function of p53. Proc Natl Acad Sci U S A. 2009;106(19):7852-7857.

23. Peidis P, Papadakis AI, Muaddi H, Richard S, Koromilas AE. Doxorubicin bypasses the cytoprotective effects of eIF2alpha phosphorylation and promotes PKR-mediated cell death. Cell Death Differ. 2011;18(1):145-154.

24. García MA, Carrasco E, Aguilera M, et al. The chemotherapeutic drug 5-fluorouracil promotes PKR-mediated apoptosis in a p53-independent manner in colon and breast cancer cells. PLoS One. 2011;6(8): e23887.

25. Yang YL, Reis LF, Pavlovic J, et al. Deficient signaling in mice devoid of double-stranded RNA-dependent protein kinase. EMBO J. 1995; 14(24):6095-6106.

26. Bunz F, Hwang PM, Torrance C, et al. Disruption of $\mathrm{p} 53$ in human cancer cells alters the responses to therapeutic agents. J Clin Invest. 1999;104(3):263-269.

27. Villalobos C, García-Sancho J. Capacitative Ca2+ entry contributes to the $\mathrm{Ca} 2+$ influx induced by thyrotropin-releasing hormone $(\mathrm{TRH})$ in GH3 pituitary cells. Pflugers Arch. 1995;430(6):923-935.

28. Yang XH, Sladek TL, Liu X, Butler BR, Froelich CJ, Thor AD. Reconstitution of caspase 3 sensitizes MCF-7 breast cancer cells to doxorubicin- and etoposide-induced apoptosis. Cancer Res. 2001;61(1): 348-354.

29. Yoon YH, Cho KS, Hwang JJ, Lee SJ, Choi JA, Koh JY. Induction of lysosomal dilatation, arrested autophagy, and cell death by chloroquine in cultured ARPE-19 cells. Invest Ophthalmol Vis Sci. 2010;51(11): 6030-6037.

30. Geng Y, Kohli L, Klocke BJ, Roth KA. Chloroquine-induced autophagic vacuole accumulation and cell death in glioma cells is p53 independent. Neuro Oncol. 2010;12(5):473-481.

31. Holcik M, Sonenberg N. Translational control in stress and apoptosis. Nat Rev Mol Cell Biol. 2005;6(4):318-327.

32. Martínez-Rivera M, Siddik ZH. Resistance and gain-of-resistance phenotypes in cancers harboring wild-type p53. Biochem Pharmacol. 2012;83(8):1049-1062.

33. Konstantakou EG, Voutsinas GE, Karkoulis PK, Aravantinos G, Margaritis LH, Stravopodis DJ. Human bladder cancer cells undergo cisplatin-induced apoptosis that is associated with p53-dependent and p53-independent responses. Int J Oncol. 2009;35(2):401-416.

34. Backus HH, Wouters D, Ferreira CG, et al. Thymidylate synthase inhibition triggers apoptosis via caspases- 8 and -9 in both wild-type and mutant p53 colon cancer cell lines. Eur J Cancer. 2003;39(9): 1310-1317.

35. Nakamura M, Nagano H, Sakon M, et al. Role of the Fas/FasL pathway in combination therapy with interferon-alpha and fluorouracil against hepatocellular carcinoma in vitro. J Hepatol. 2007;46(1):77-88.

36. Philchenkov A, Zavelevich M, Kroczak TJ, Los M. Caspases and cancer: mechanisms of inactivation and new treatment modalities. Exp Oncol. 2004;26(2):82-97.

37. Janicke RU, Ng P, Sprengart ML, Porter AG. Caspase-3 is required for alpha-fodrin cleavage but dispensable for cleavage of other death substrates in apoptosis. J Biol Chem. 1998;273(25):15540-15545.

38. Akar U, Chaves-Reyez A, Barria M, et al. Silencing of Bcl-2 expression by small interfering RNA induces autophagic cell death in MCF-7 breast cancer cells. Autophagy. 2008;4(5):669-679.

39. Xue L, Fletcher GC, Tolkovsky AM. Autophagy is activated by apoptotic signalling in sympathetic neurons: an alternative mechanism of death execution. Mol Cell Neurosci. 1999;14(3):180-198.

40. Lee HK, Lund JM, Ramanathan B, Mizushima N, Iwasaki A. Autophagy-dependent viral recognition by plasmacytoid dendritic cells. Science. 2007;315(5817):1398-1401.

41. Desai MM, Gong B, Chan T, et al. Differential, type I interferonmediated autophagic trafficking of hepatitis $C$ virus proteins in mouse liver. Gastroenterology. 2011;141(2):674-685. 
42. Akiyama M, Iwase S, Horiguchi-Yamada J, et al. Interferon-alpha repressed telomerase along with G1-accumulation of Daudi cells. Cancer Lett. 1999;142(1):23-30.

43. Li Q, Tang L, Roberts PC, et al. Interferon regulatory factors IRF5 and IRF7 inhibit growth and induce senescence in immortal Li-Fraumeni fibroblasts. Mol Cancer Res. 2008;6(5):770-784.
44. Upreti M, Koonce NA, Hennings L, Chambers TC, Griffin RJ. Pegylated IFN-alpha sensitizes melanoma cells to chemotherapy and causes premature senescence in endothelial cells by IRF-1 mediated signaling. Cell Death Dis. 2010;1:e67.

\section{Publish your work in this journal}

Drug Design, Development and Therapy is an international, peerreviewed open-access journal that spans the spectrum of drug design and development through to clinical applications. Clinical outcomes, patient safety, and programs for the development and effective, safe, and sustained use of medicines are a feature of the journal, which has also been accepted for indexing on PubMed Central. The manuscript management system is completely online and includes a very quick and fair peer-review system, which is all easy to use. Visit http://www.dovepress.com/testimonials.php to read real quotes from published authors.

Submit your manuscript here: http://www.dovepress.com/drug-design-development-and-therapy-journal 